
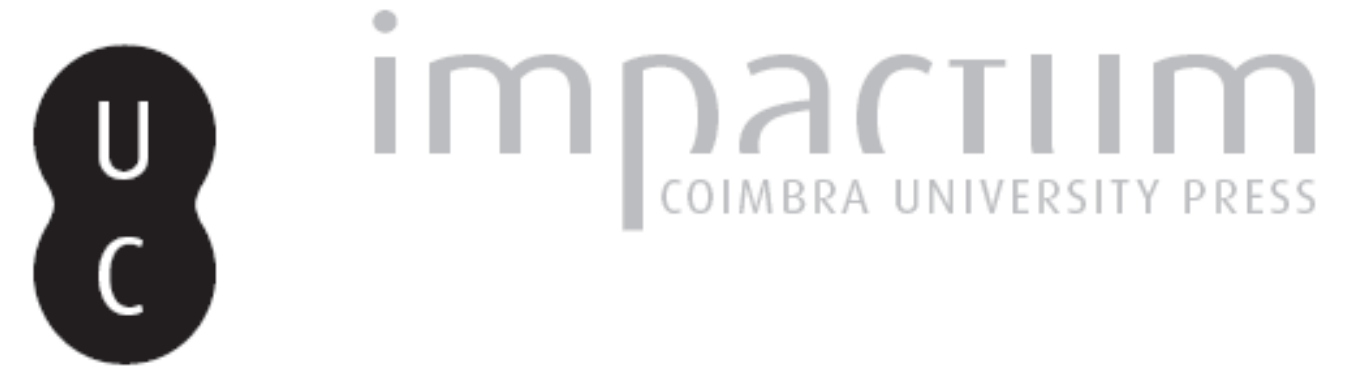

\title{
Socrates in the Cave: platonic epistemology and the common man
}

\author{
Autor(es): $\quad$ Erler, M.
}

Publicado por: Imprensa da Universidade de Coimbra

URL persistente: URI:http://hdl.handle.net/10316.2/42249

DOI: $\quad$ DOI:https://doi.org/10.14195/2183-4105_4_3

Accessed : $\quad$ 26-Apr-2023 11:04:37

A navegação consulta e descarregamento dos títulos inseridos nas Bibliotecas Digitais UC Digitalis, UC Pombalina e UC Impactum, pressupõem a aceitação plena e sem reservas dos Termos e Condições de Uso destas Bibliotecas Digitais, disponíveis em https://digitalis.uc.pt/pt-pt/termos.

Conforme exposto nos referidos Termos e Condições de Uso, o descarregamento de títulos de acesso restrito requer uma licença válida de autorização devendo o utilizador aceder ao(s) documento(s) a partir de um endereço de IP da instituição detentora da supramencionada licença.

Ao utilizador é apenas permitido o descarregamento para uso pessoal, pelo que o emprego do(s) título(s) descarregado(s) para outro fim, designadamente comercial, carece de autorização do respetivo autor ou editor da obra.

Na medida em que todas as obras da UC Digitalis se encontram protegidas pelo Código do Direito de Autor e Direitos Conexos e demais legislação aplicável, toda a cópia, parcial ou total, deste documento, nos casos em que é legalmente admitida, deverá conter ou fazer-se acompanhar por este aviso.

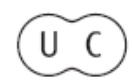




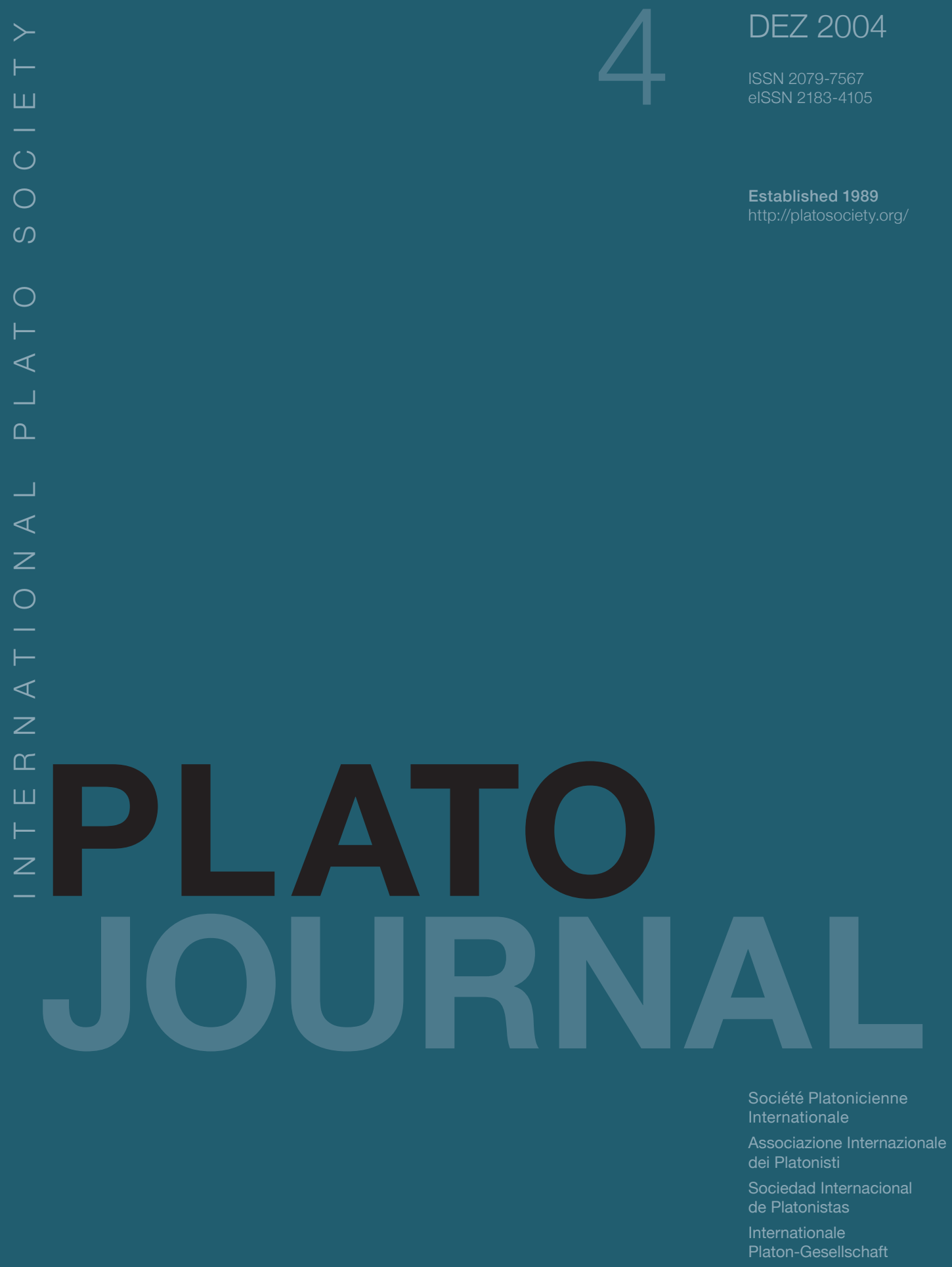


SOCRATES IN THE CAVE.

Platonic EPISTEMOLOGY AND THE COMMON MAN

1. It is well known that Plato defines knowledge in terms of ontological categories. Real knowledge for him means grasping the ideas. This knowledge can be gained by searching within oneself. Only philosophers, however, are able to attain knowledge this way, transforming themselves into the status of gods as far as it is possible for men. ${ }^{1}$ Plato clearly describes an ideal in the dialogues. But Plato also addresses the common man's potential for achieving knowledge despite his deficient condition in comparison to the Platonic ideal. In the famous simile of the cave in the Republic, Plato offers a quite realistic view of common man as being emprisoned in a world of becoming. ${ }^{2}$ This prisoner takes pictures on the wall for reality. In order to be freed from this illusion, he has to be turned around toward truth. The prisoners, however, are not able to turn around themselves without help from outside. What they need is a teacher who asks them questions and gets them into conceptual difficulties (aporiai). ${ }^{3}$ Common man also is likely to have emotions, desires, and

* This is part of a larger project that also will deal both with Plato and the tradition of the metaphor 'child in man' in ancient philosophical contexts.

${ }^{1}$ Passages: D. Sedley: 'Becoming like God' in the Timaeus and Aristotle', in: T. Calvo, L. Brisson (edd.): Interpreting the Timaeus - Critias. Proceedings of the IV Symposium Platonicum. Selected Papers (Sankt Augustin 1997) [International Plato Studies 9], 327-339 and D. Sedley: 'The Ideal of Godlikeness,' in: G. Fine (ed.): Plato 2. Ethics, Politics, Religion, and the Soul (Oxford 1999), 309-328.

${ }^{2}$ Th. A. Szlezák: 'Das Höhlengleichnis (Buch VII 514a-521b und 539d541b), in: O. Höffe (Hg.) Platon, Politeia (Berlin 1997) [Klassiker auslegen 7], 205-228.

${ }^{3}$ Cf.: R. 515c, see: J. Annas: An Introduction to Plato's Republic (Oxford 1989), 258f. and M. Erler: 'Hilfe der Götter und Erkenntnis des Selbst. Sokrates als Göttergeschenk bei Platon und den Platonikern,' in: Th. Kobusch, M. Erler (edd.): Metaphysik und Religion. Zur Signatur des spätantiken Denkens. Akten des Internationalen Kongresses vom 13.-17. März 2001 in Würzburg (Munich, Leipzig 2002) [BzA 160], 387-413. N.

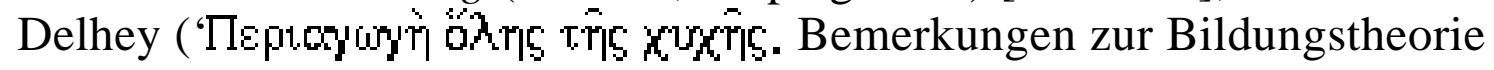
in Platons Politeia,' in: Hermes 122 (1994), 44-54, esp. 47ff.) rightly 
fears that make him deaf to rational persuasion, and that might overpower his rational thinking and cause him to act against his will $(R$. 519a-b). The teacher therefore must try to create the kind of disposition in his partner that prepares him to accept the results of rational arguments, makes him realize what is true and what is false, and helps him to transform this knowledge into moral behavior. ${ }^{4}$ In the Timaeus, Plato postulates that both the immortal rational self and the mortal self need therapy ( $T i$. 90a-c), in order "to set even the baser part of us on the right path in this way" (71d, transl. Cornford). Of course, Plato believes that one can achieve real knowledge only if one focuses on the immortal soul. But as the Athenian stranger in the Laws shows, moral practice too is of crucial importance for gaining knowledge. Harmonizing the parts of the soul and controlling desires and fears, which are located in the mortal part of the soul, require self-control. ${ }^{5}$

For the common man, the therapy of the mortal self and the proper control of affections are essential for developing the right habits that provide the foundation for virtue and real knowledge. Paramythia, the therapy of human passion that produces a particular emotional change in man so that he becomes more amenable to advice and a better learner ( $L$ g. 718cd), is central in the so-called 'little or basic Paideia' not only in the Laws (734e-735a), but also in the Republic. Without this groundwork, this praeparatio philosophica, common man will fail to act in accordance with the judgements and insights that emerge from conversation. To resist right opinion is regarded as lack of knowledge. ${ }^{6}$

2. The theoretical underpinning for the phenomenon that emotions, desires, or affections like fear can prevent one from accepting the results

stresses, that this does not happen simply by nature (so L. C. H. Chen: 'Education in General (Rep. 518c4-519b5),' in: Hermes 115 (1987), 6672), but by force.

${ }^{4}$ Cf. $R .401 \mathrm{~d}-402 \mathrm{a}$.

${ }^{5}$ M. Erler: 'Epicurus as deus mortalis. Homoiosis theoi and Epicurean Self-cultivation,' in: D. Frede, A. Laks (edd.): Traditions of Theology. Studies in Hellenistic Theology, Its Background and Aftermath (Leiden 2002) [Philosophia Antiqua 89], 159-181, esp. $165 f$.

${ }^{6}$ Cf. Lg. 689a; see: K. Schöpsdau: Platon, Nomoi (Gesetze) Buch I-III. Übersetzung und Kommentar (Göttingen 1994) [Platon, Werke 9,2], 41417. 
of rational argument is the soul's partitioning which Plato develops in the Republic. This partitioning of the soul explains why reason sometimes is overcome by emotion against its will. ${ }^{7}$

Often this is regarded to be a new insight of Plato's in the Republic, because no evidence for the soul's partitioning can be found before the Republic. This is the thesis I wish to challenge. I shall argue that Plato in the Phaedo playfully considers the existence of something in man that is responsible for emotions, desires, and fear, and that is distinct from both the body and the rational soul. In the Phaedo, Plato even gives this source of emotions a name: he calls it the 'child in man' --and he illustrates how it should be treated by therapeutic arguments, in order to create a disposition that is amenable to rational thinking. I also wish to draw attention to the fact that both this metaphor and the method of praeparatio philosophica for gaining knowledge was to play an important role in the philosophical curriculum from Plato onwards, in Hellenistic philosophy as well as in the Platonism of imperial times. ${ }^{8}$

3. Let us have a look at the Phaedo. In this dialogue, Socrates illustrates the power of the logos or rational argument in helping Socrates to be brave and fearless in the face of death, and enabling him to accept rational arguments in favor of the soul's immortality. Contrary to common opinion, this dialogue does not teach one how to repress emotions because these are the effect of the soul's imprisonment in the body. ${ }^{9}$ Rather, the Phaedo illustrates how to handle emotions that spring from a source that is distinct from the body, emotions which cannot be eradicated, but have to be controlled, because they disturb rational thinking. The exemplum Socratis illustrates how this can be done successfully. His partners Crito,

${ }^{7}$ L1. P. Gerson: Knowing Persons. A Study in Plato (Oxford 2003), 265. I doubt that Ch. Bobonich, Plato's Utopia Recast. His Later Ethics and Politics (Oxford 2002), is right in arguing that this partitioning of the soul in the Republic later was regarded as an error by Plato and corrected in the Laws.

${ }^{8}$ I hope to develop this elsewhere.

${ }^{9}$ See D. Gallop: 'Emotions in the Phaedo,' in: A. Havlícek, F. Karfík (Edd.): Plato's Phaedo, Proceedings of the Second Symposium Platonicum Pragense (Prague 2001), 275-286; cf. J. Dalfen, 'Philologia und Vertrauen: Über Platons eigenartigen Dialog Phaidon,' in: GB 20 (1994), 35-57. 
Cebes, and Simmias, on the other hand, illustrate what happens if emotions prevail, and man is not able to subordinate these to reason. Crito, for his part, remains unmoved by the arguments, and draws wrong conclusions (115c). Cebes and Simmias, in contrast, are used to arguments. They are well prepared to follow Socrates' arguments in favor of the soul's immortality, and to accept the conclusions of rational thinking. Nevertheless, they do display insecurity and distrust, while not being able to give a reason for this unease. Something within them is out of control and prevents them from accepting the results of what they agree are coherent arguments. ${ }^{10}$ This deep-rooted fear Socrates wishes to treat by means of his 'paramythic' arguments, with which he wishes to address both the ratio and the emotions of his partners. ${ }^{11}$

It is interesting that in this context, Plato's Socrates does not locate Cebes' and Simmias' emotions in the body, as he does elsewhere in the Phaedo. ${ }^{12}$ No, Plato invents a metaphor to describe the source of the affections of Socrates' partners and the target of Socrates' therapeutic argumentation. At one point, Socrates suspects that Cebes and Simmias are afraid like children that wind might disperse the soul after death. Cebes points out that it is not he himself who is afraid, but that rather something within himself --a child within himself, as he calls it-- is full of fear, like children of a bogey (77d-e). He therefore begs Socrates (77d): "Try to convince us, then, Socrates, on the assumption that we are afraid; or rather, not as though we are afraid - perhaps there is a child inside us ${ }^{13}$

${ }^{10}$ Cf. Phd. 77e, 91c-d. 107b.

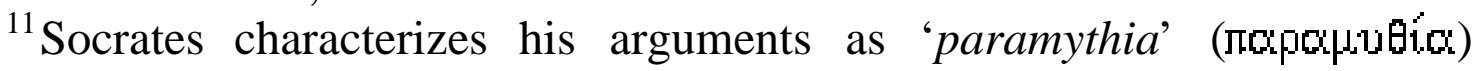
(Phd. 70b, 83a).

${ }^{12}$ Cf. Phd. 81b-c, 94b-c. See: N. Blössner: 'Sokrates und sein Glück, oder: Warum hat Platon den Phaidon geschrieben?,' in: A. Havlícek, F. Karfík (Edd.): Plato's Phaedo, Proceedings of the Second Symposium Platonicum Pragense (Prag 2001), 96-139, esp. 129ff.

${ }^{13}$ Phd. 77e. I agree with Wyttenbach (Platonis Phaedo, explanatus et emendatus prolegomenis et annotatione Dan. Wyttenbachii, Lugdunum Batavorum 1810) that the metaphor has to be understood as "child within us' and I disagree with Ficino (Platonis opera translatione Marsilii Ficini, emendatione et ad Graecum codicem collatione Dimonis Grynaei 1533) and others, who translate inter nos puer. There has been a discussion as to whether the metaphor means doubtful reason (Chr. F. Williger: 'Il nois Di Cebes Nel Фळibuv Di Platone,' in: GM 1 (1946), 
that is apprehensive in this way. So try to persuade him not to be afraid of the bogey Death. Try to persuade him, then, to stop being afraid of death as if it were a bogey-man." And Socrates consents readily: "You must sing charms over him (epodai), said Socrates, every day, until you have charmed the fear out of him."

'To charm the fear out of the child in man as philosophical praeparatio,' this is what Socrates' rational arguments in the Phaedo are meant to accomplish. This is what Socrates' 'paramythia' and philosophical 'epode" ${ }^{14}$ are for: to combine rational arguments with therapeutic intentions.

It is useful at this point to remind ourselves that the metaphor the "child in man which needs persuasion in order to rid itself of the fear of death' has a 'Sitz im Leben.' It forms part of the paideia that tries to make children act properly. Plato wishes to remind us of the 'old wives' tales that nurses told children in Greece, as people still do today, in order to frighten children into obedience: "If you don't do such and such, a monster will come and eat you." Those traditional tales are meant to create fear in children, and thereby a disposition to accept advice. ${ }^{15}$

103-113) or an irrational part of the soul (G. Capone Braga, 'Il "Fanciullino" Di Cebete,' in: GM 2,1947, 60-62, with a response by Chr. F. Williger: 'Ancora Sul "Fanciullino" Di Cebete,' in: GM 2, 1947, 262264); see also C. H. Young: 'A Delicacy in Plato's Phaedo,' in: CQ NS 38,1988, 250-251).

${ }^{14}$ Cf. P. Lain-Entralgo: 'Die platonische Rationaliserung der Besprechung

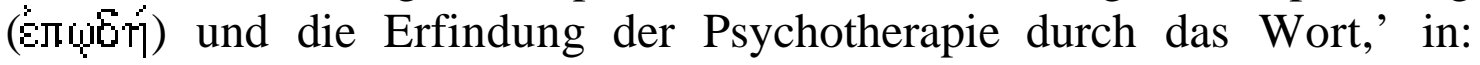
Hermes 86 (1958), 298-323. Epode as rational argument: cf. Plat. Chrm. 156e-157a; Phd. 77e, Lg. 903a-b, and Chr. Bobonich, 'Persuasion, Compulsion and Freedom in Plato's Laws,' in: CQ NS 41 (1991), 365388, bes. 374. The Charmides shows, that philosophical argument and teaching should follow the protreptic praeparatio philosophica by means of the aporia. Cf. M. Erler: Der Sinn der Aporien in den Dialogen Platons (Berlin, New York 1987) [UaLG 25], $211 \mathrm{f}$.

${ }^{15}$ Cf. A. Scobie: 'Storytellers, Storytelling, and the Novel in GraecoRoman Antiquity,' in: RhM 122 (1979), 229-259 and G. Heldmann: Märchen und Mythos in der Antike? Versuch einer Standortbestimmung (Munich, Leipzig 2000) [BzA 137], 95ff., who does not mention the passage in the Phaedo. 
Seen against this background, parallels and differences become evident. Socrates' rational epode indeed tries to create a disposition in his partners that is amenable to rational arguments and to correct behavior. Socrates, however, does not wish to achieve this result by stirring up fears in his partners, but by helping them to control those fears, or rather to get rid of them altogether. Socrates' 'charming' arguments advocate the subordination of the emotions to reason, because emotions might subvert rational thinking. Philosophical arguments in the Phaedo are part of the praeparatio philosophica which Plato discusses in the Republic, but mainly in the Laws, advocating a symphonia of emotions and ratio in man. ${ }^{16}$ In the Phaedo, Plato recognizes that logical reason by itself is not enough to shape moral attitudes.

As early as in the Phaedo, Plato expresses the need to introduce an element in man that might explain why reason can lose out to emotions, and why man therefore hesitates to accept the results of rational thinking, although he feels that the arguments are strong and persuasive. ${ }^{17}$ In the Phaedo, Plato locates the source of this emotional resistance neither in the body nor in the rational soul, but invents the metaphor 'child in man' --a metaphor that, it seems to me, foreshadows the soul's irrational part, which Plato introduces in the Republic. In other words, the Republic --in my opinion-- merely unfolds what the Phaedo seems to assume. This interpretation is underscored by the fact that in the 4th book of the Republic, Plato draws on the same argument -the competition between thirst and judgement --which he uses in the Phaedo to describe the possibility for conflict in the soul (94b). ${ }^{18}$ Plato often uses metaphors in one place, and explains what they mean philosophically elsewhere in his dialogues. ${ }^{19}$ I agree that prior to the Republic, Plato does not refer to a tripartitioning of the soul. ${ }^{20}$ But I wish to argue that a metaphor like

${ }^{16}$ Cf. Plato Laws 652a-653c, cf. Schöpsdau: Plato. Nomoi I-III (as in n.6), 255.

${ }^{17}$ Also of interest in this context are passages like Grg. 513c, Men. 95c. I shall deal with these elsewhere.

${ }^{18}$ Cf. Bobonich: Plato's Utopia Recast (as in n. 7), 30.

${ }^{19}$ See E. E. Pender: Images of Persons Unseen. Plato's Metaphors for the Gods and the Soul (St. Augustin 2000). She, however, does not deal with Plato's metaphor 'child in man.'

${ }^{20}$ Ll. Gerson: Knowing Persons (as in n. 7), 98. 
'child in man' signals that Plato contemplates the possibility of an element within man's soul that is responsible for irrational behavior.

As early as in the Phaedo, then, Plato already reflects on the ways of preparing one's disposition for being 'turned around' in order to attain knowledge. And he illustrates what 'charming the child in man' entails: a therapy that not necessarily ends up in new knowledge, but that might bring reason and the emotions into harmony, and creates a disposition that is the proper basis for attaining knowledge. Without being an orthodox unitarian in Platonicis, I think there is lot to be said about elements of continuity in Platonic epistemology in connection with the praeparatio philosophica. Differences do exist, but these might be due to the different contexts in Plato's literary dialogues.

Let me conclude by pointing out that in Antiquity, the metaphor 'charming the child in man' was very influential and was understood in the manner I developed here. Plato, I think, would agree with Epicurus' dictum, which many other Hellenistic philosophers accepted, that "empty is that philosophers' discourse which offers therapy for no human passion." "21 From Hellenistic times all the way up to Late Antiquity, the 'child in man as addressee of therapeutic arguments' became a tag for the praeparatio philosophica that prepares the proper dispositio of the would-be-philosopher who is on his way to real knowledge. ${ }^{22}$

M. Erler

University of Würzburg

${ }^{21}$ Vgl. Us. 221.

${ }^{22}$ See. M. Erler: 'Death is a Bugbear. Socratic 'epode' and Epictetus' Philosophy of the Self,' in: Zeno and his Legacy: the Philosophy of Epictetus (forthcoming), and M. Erler: 'Das Bild vom 'Kind im Menschen' bei Platon und bei Lukrez,' in: CErc. (2003) (in print). 